УДК 004.932.7

Сугоняк Інна Іванівна

кандидат технічних наук, доцент кафедри програмного забезпечення систем Житомирський державний технологічний університет, м. Житомир, Україна isygon@mail.ru

\title{
ОLАР-ТЕХНОЛОГІЇ ДЛЯ МОНІТОРИНГУ УСПІШНОСТІ СТУДЕНТІВ ЗА УМОВ РЕЙТИНГОВОЇ СИСТЕМИ ОЦІНЮВАННЯ ЗНАНЬ
}

\begin{abstract}
Анотація. У статті висвітлені проблемні аспекти впровадження інформаційних технологій у освітню діяльність вищих навчальних закладів, визначені завдання комплексного моніторингу успішності студентів, проаналізовано сучасні технології багатовимірного аналізу даних зокрема, концепція Data Mining і OLAP-технології, визначені можливості й напрямки використання засобів багатовимірного аналізу даних у системах моніторингу успішності студентів, виконано об'єктно-орієнтоване проектування програмного комплексу системи з використанням мови UML, обгрунтований вибір платформи реалізації й наведено опис прототипу системи.
\end{abstract}

Ключові слова: рейтингова система оцінювання знань; OLAP-технології; інформаційні системи в освіті.

\section{1. ВСТУП}

Питання впровадження інформаційних і комунікаційних технологій в управління навчальним процесом у вищому навчальному закладі (ВН3) є невід'ємною складовою створення перспективної системи освіти, здатної підготувати висококваліфікованого конкурентоспроможного спеціаліста. У рамках Державної національної програми «Освіта» («Україна XXI століття») передбачено, що розвиток освіти досягається за рахунок використання нових прогресивних концепцій і підходів й упровадженням у навчально-виховний процес новітніх інформаційних технологій [1]. Важливим напрямом використання інформаційних систем в освіті є створення не тільки систем обліку успішності навчання студентів, але й аналітичних систем моніторингу якості освіти.

Постановка проблеми. У рамках традиційної паперової технології обробки й обміну даними неможливо реалізувати задачі, які ставляться перед сучасними комп'ютеризованими системами контролю успішності студентів. Тому актуальним $є$ завдання реорганізації систем управління ВНЗ і керування даними з метою організації найефективнішої роботи.

Аналіз останніх досліджень і публікацій. Аналіз джерел [1; 3] показав, що більшість ВНЗ використовують інформаційні системи для виконання адміністративної роботи, а саме формування і друку екзаменаційних і залікових відомостей, заявок на виготовлення документів про освіту і студентських квитків, планування навчального процесу, складання розкладу навчальних занять тощо. Значна кількість освітніх закладів використовують програмні засоби для часткової автоматизації розв'язання завдань, що призводить до дублювання інформаційних потоків даних, можливості їх втрати, відсутності можливості аналізу даних, підвищення ролі людського чинника. Згідно з ISO 9001:2009 «Система управління якістю. Вимоги» ВНЗ, як організація, що надає певний вид послуг, має здійснювати моніторинг і контроль якості, проводити аналіз даних і покращувати результати системи управління якістю [2].

Упровадження інформаційних технологій в освітніх закладах ускладнене високою вартістю готових рішень i наявною необхідністю їх підтримки сторонніми 
спеціалістами. Готові програмні системи, що їх пропонують фірми-розробники містять у своєму складі стандартну систему звітності, а додаткові форми доопрацьовують за замовленням ВНЗ. Натомість, забезпечення інформаційною статистикою викладачів i адміністрації ВНЗ є вкрай низьким, адже грунтується лише на стандартному звіті якісна/абсолютна успішність по групі. 3 іншого боку, кредитно-модульна система організації навчального процесу і запроваджена разом 3 нею рейтингова система оцінювання знань студентів дозволяють, а, отже, й вимагають здійснювати всебічний аналіз успішності студентів з урахуванням поточних оцінок і підсумкових результатів, врахуванням персоналій викладачів, що беруть участь в навчальному процесі, попереднього рівня підготовленості студентів та інших факторів. Отже, необхідним є використання сучасних засобів багатовимірного аналізу даних для діагностування стану навчального процесу. Для готових систем процес модернізації звітних форм $є$ витратним, тому ВНЗ потребують запровадження таких рішень, які дозволяють користувачам самостійно створювати звітні форми багатовимірного аналізу даних. Наразі рівень кваліфікації користувачів є відповідним базовим навичкам фахівця 3 вищою освітою, які грунтуються на нормативних дисциплінах «Інформатика» й «Інформаційні технології в галузі», що, по суті, означає володіння базовими прийомами роботи в пакеті офісних додатків MS Office й одному-двох спеціалізованих додатках.

Отже, актуальною $\epsilon$ розробка системи моніторингу успішності 3 метою автоматизації процесу контролю якості навчання студентів ВНЗ із використанням багатовимірних технологій аналізу даних, низькою вартістю обслуговування, гнучким інструментарієм формування звітності, що розрахована на користувачів без спеціальних навичок роботи із СКБД і програмними комплексами.

Мета статті. Сучасний стан інформатизації навчального процесу формує проблему дослідження автоматизації моніторингу успішності студентів із використанням багатовимірних технологій обробки даних для збільшення ефективності й результативності діяльності працівників деканату, підвищення достовірності i своєчасності обробки даних про успішність студентів, забезпечення зростання якості навчання на основі результатів аналізу сесії. Основне призначення даної системи - це створення i ведення інформаційної бази для надання необхідної статистичної інформації щодо успішності студентів, аналіз стану і динаміки якості навчання. Проектування даної системи виконане з використанням CASE-засобів проектування ALL-fussion Data Modeler i Rational Rose (UML), реалізацію автоматизованої системи виконано засобами СКБД MS SQL Server i MS Access.

\section{2. МЕТОДИ ДОСЛІДЖЕННЯ}

Під час дослідження використовувались такі методи: аналіз теоретичних джерел із проблем упровадження інформаційних технологій у діяльність закладів освіти, організації моніторингу навчальних результатів, вивчення й узагальнення передового досвіду організації застосування інформаційних технологій для моніторингу, сучасний інструментарій аналізу даних в on-line системах.

\section{3. РЕЗУЛЬТАТИ ДОСЛІДЖЕННЯ}

Метою оцінювання успішності студентів є комплексна оцінка якості навчальної роботи студентів під час опанування ними освітньо-професійної програми підготовки. Основні задачі рейтингового оцінювання успішності полягають у підвищенні мотивації студентів до опанування навчального матеріалу шляхом більш високої диференціації 
оцінки їх навчальної роботи, підвищення мотивації спільної рівномірної роботи викладачів і студентів протягом семестру, а також у підвищенні рівня організації навчального процесу в університеті. Альтернативою традиційним методам аналізу даних, заснованим на різних системах реалізації SQL-запитів до реляційної бази даних $\epsilon$ технологія оперативної аналітичної обробки даних (OLAP). Дана технологія може бути реалізована на основі універсальних реляційних СКБД або спеціалізованим програмним забезпеченням.

В основі OLAP лежить багатовимірна модель представлення даних, у якій на зміну таким поняттям, як відношення і сутності приходять поняття вимірів і кубів даних. 3 точки зору інформаційних технологій OLAP-куб є багатомірним масивом даних тривалого зберігання.

Багатомірність представлення даних дозволяє:

1) зробити механізм отримання даних більш доступним й інтуїтивно зрозумілим аналітику;

2) позбавитись обмежень мови SQL через принципову зміну алгоритму створення звітів засобами OLAP.

Так, наприклад, підрахунок сумарних величин уже не вимагає часу безпосередньо на етапі аналізу, оскільки всі можливі суми вже підраховані на етапі побудови багатовимірної бази даних. Реляційна база даних, що містить всю статистичну інформацію про предметну область, перетворюється на сховище даних у термінах OLAP, а процес створення структури аналітичної системи зводиться до визначення вимірів й організації вітрин (зрізів) даних.

B OLAP-кубах виміри (dimensions) або осі куба відповідають - індексам масиву, а міри (measures) куба — значенням елементів масиву.

$$
w:(x, y, z) \rightarrow w_{x y z},
$$

де $x, y, z-$ виміри, $w$ - міра.

Основною відмінністю OLAP-куба від звичайного масиву є спосіб організації доступу до елементів: його можна здійснювати як за повним набором індексів-вимірів, у такому випадку результатом буде один елемент, так і за підмножиною індексіввимірів - результатом буде множина елементів.

$$
W:(x, y) \rightarrow W=\left\{w_{z 1}, w_{z 2}, \ldots, w_{z n}\right\} .
$$

3 точки зору реляційної алгебри - OLAP-куб реалізує проекцію відношень. Для $N$-вимірного відношення проекція з вимірами $X, Y$, ключовим виміром $Z$ та різницевим атрибутом - $W$ визначена функцією:

$$
W:(X, Y, Z) \rightarrow W,
$$

де атрибутам $(X, Y, Z)$ відповідають осі куба, а значення $W$ для кожної 3 можливих трійок $(X, Y, Z)$ відповідають даним, що містяться в окремих комірках куба. Оскільки в наш час для двовимірних пристроїв виведення даних не можлива чотиривимірна адресація, більш практичним є проектування «зрізів» куба у вигляді:

$$
W:(X, Y) \rightarrow W
$$

У даній проекції відсутній первинний ключ. Тому можлива деяка багатозначність функції. У будь-якому випадку отримання функціонального представлення за визначеним зрізом $Z \in$ дуже зручним для підсумкового аналізу даних і агрегування підсумків [5].

Використання багатовимірних кубів даних є зручним інструментом і в роботі 3 управлінською звітністю. Це пов'язане 3 тим, що для ефективного прийняття управлінських рішень потрібна звітність високого рівня деталізації. Тому в сучасних інформаційних системах проектується й реалізується велика кількість аналітичних зрізів за різними вимірами, які визначаються довідниками (довідниковими таблицями 
БД, що містять статичну інформацію щодо бізнес-процесів). Тому статичні звіти затвердженого зразка вже не влаштовують сучасних керівників, які є «просунутими» споживачами інформаційних продуктів. Необхідним $\epsilon$ динамічне представлення інформації, яке можуть забезпечити лише OLAP-технології. Отже, OLAP-технології вже зараз стали обов'язковим елементом програмних комплексів сучасних i перспективних інформаційних систем.

Згідно [2] основними функціями системи моніторингу успішності студентів $€$ реєстрація даних щодо поточної успішності і представлення іiї у зручній для користувачів (студенти, викладачі та працівники деканату) формі, зокрема у формі підсумкових відомостей в розрізі групи, дисципліни, студента тощо. Тому, у даному випадку використання OLAP-технологій $є$ найкращим інструментарієм формування звітності.

Для проектування програмного комплексу інформаційної системи моніторингу успішності студентів було використано уніфіковану мову моделювання UML. Об'єктно-орієнтована модель системи розроблена за допомогою інтегрованого середовища Rational Rose 2003.

Інформаційна система моніторингу успішності студентів може використовуватись у деканаті факультету ВНЗ у таких випадках (рис. 1): для збереження даних про зміни у навчальних планах; введення даних 3 електронних відомостей про результати екзаменаційно-залікової сесії; формування загальних рейтингів за студентом, групою і курсом та формуванням подальших звітів про стипендіатів і боржників.

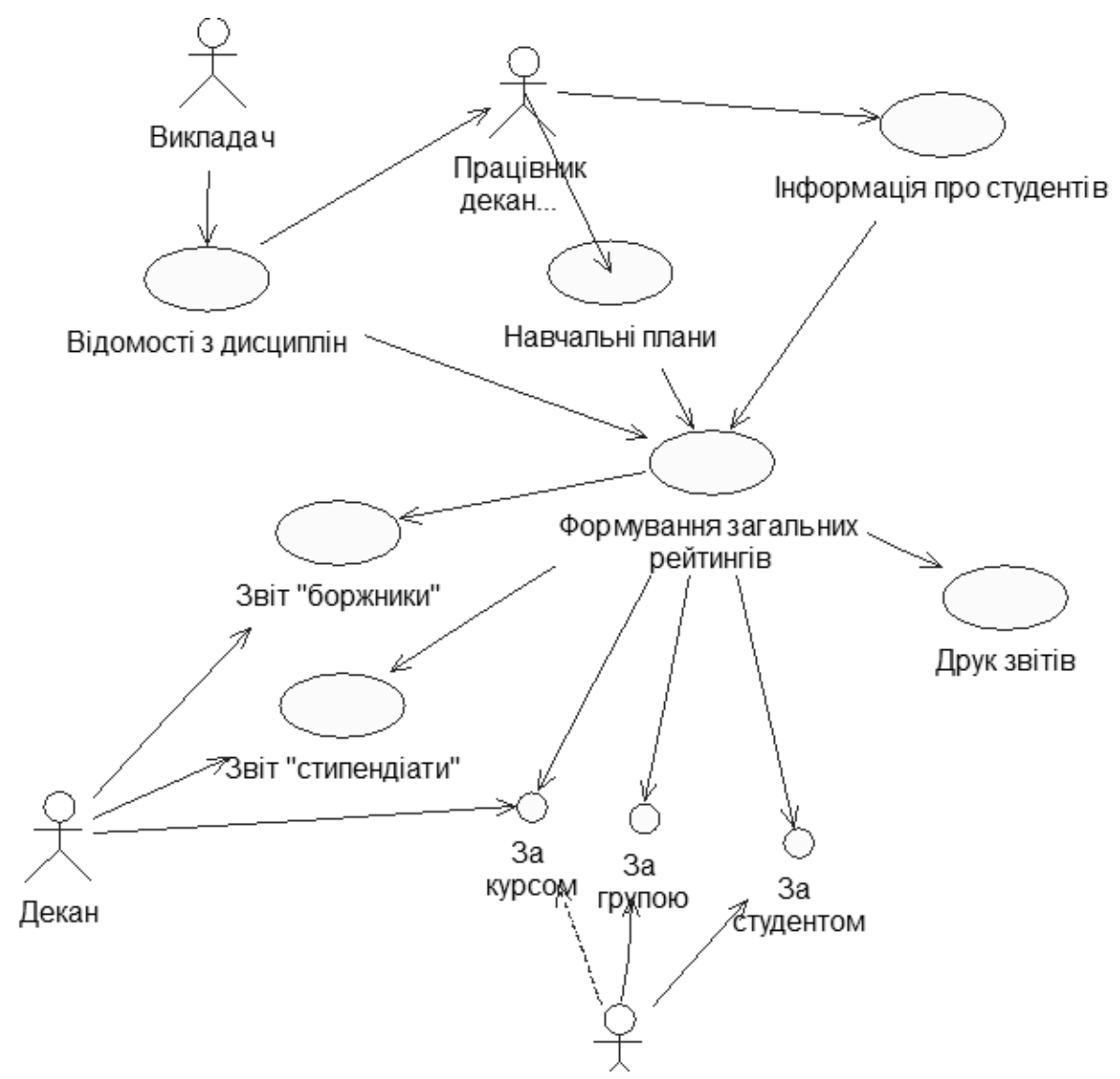

Рис. 1. Діаграма варіантів використання автоматизованої системи

Класи, які утворюють програмний комплекс автоматизованої системи моніторингу успішності, і їх взаємозв’ язки, наведено на відповідній діаграмі (рис. 2). 


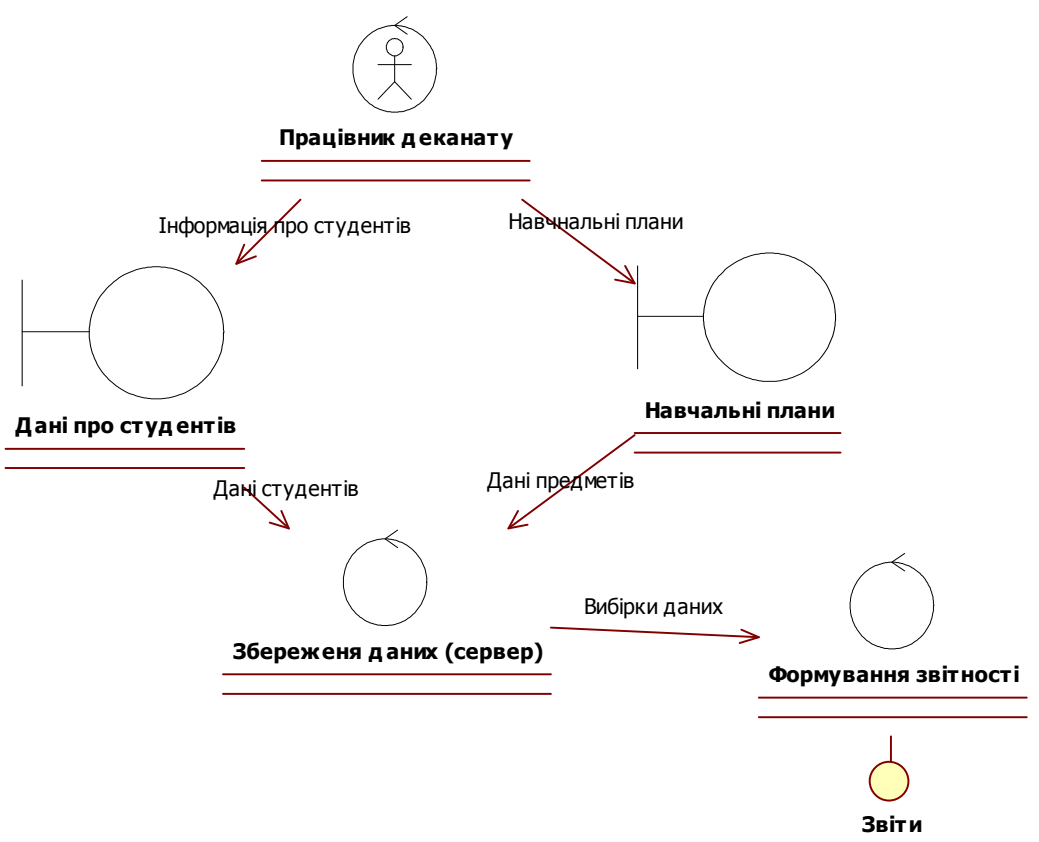

Рис. 2. Діаграма взаємодї класів системи

Порядок обробки даних можна умовна розбити на чотири блоки.

Блок I. «Розрахунок успішності студентів» - у цьому блоці проводиться сумування всіх балів студентів з різних предметів і формування рейтингів.

Блок II. «Абсолютна успішність» - у даному блоці визначається загальна успішність студентів, яка відображається у наступних зрізах: «по групі», «за період», «по дисципліні» та ін.

Блок III. «Якісна успішність» - у цьому блоці визначаються показники якісної успішності на основі даних отриманих у другому блоці.

Блок IV. «Формування звітності» — у даному блоці реалізоване формування графіків успішності і виведення результатів рейтингів у вигляді форм для друку.

Діаграма компонентів інформаційної системи моніторингу успішності студентів, наведена на рис. 3, відображає залежності між компонентами програмного забезпечення. На головній формі клієнтського додатка розміщено вкладки «Аналіз успішності» для узагальнення результатів навчання студентів, «Графіки» для виведення інформації у вигляді гістограм розподілу і колових діаграм та «Дані» для введення i перегляду даних про студентів факультету, навчальні плани та результати оцінювання.

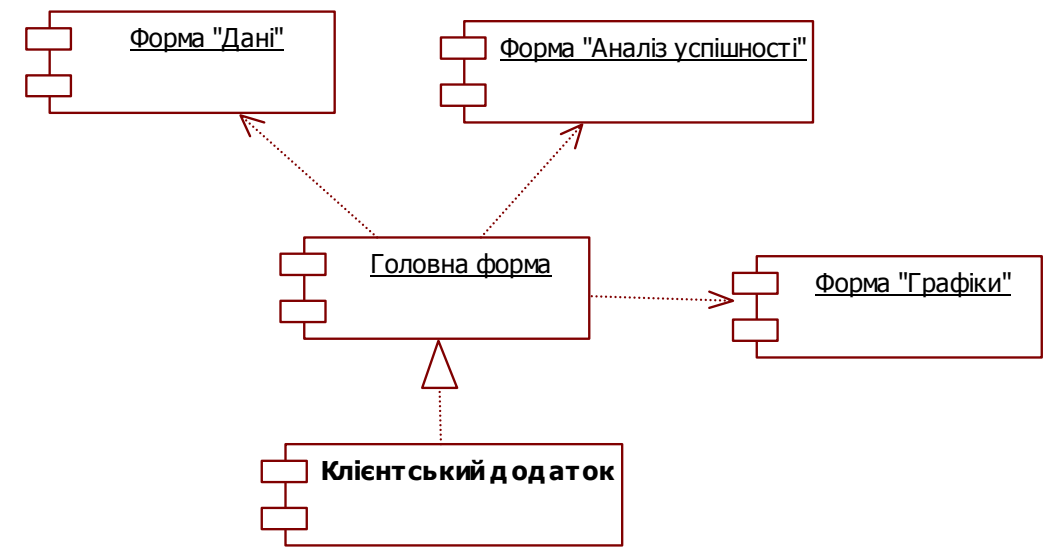

Рис. 3. Діаграма компонентів автоматизованої системи моніторингу 
Для моделювання апаратних засобів автоматизованої системи й артефактів, розгорнутих на них, використано діаграму розгортання (рис. 4). На ній показано, що система функціонує в локальній мережі деканату, яка складається з робочих станцій, які через сервер додатків отримують дані із сервера бази даних, на якому вони зберігаються. Виведення необхідної документації на друк виконується через принтер, підключений до локальної мережі.

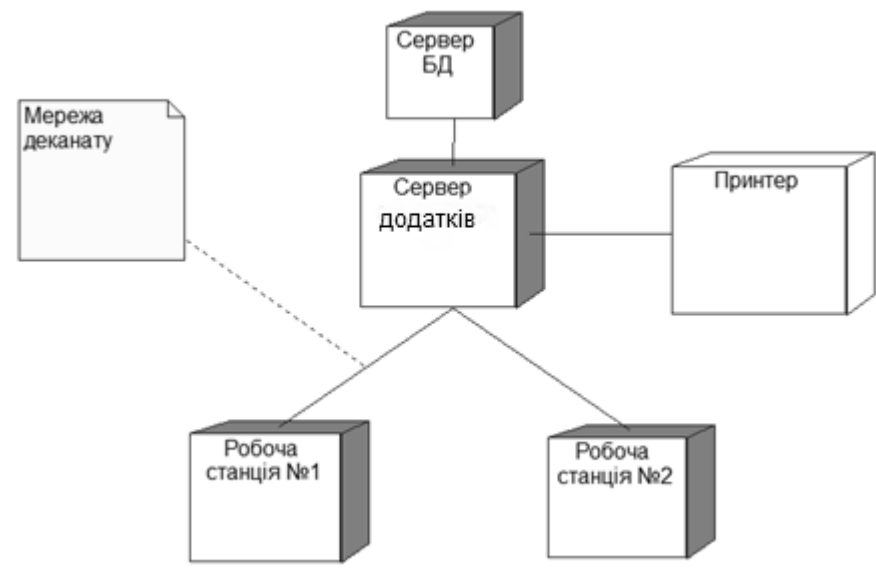

Рис. 4. Діаграма розгортання системи

Отже, застосування універсальної мови моделювання UML дозволило визначити, візуалізувати та задокументувати об' єктні моделі програмного забезпечення системи. У свою чергу це дало змогу спростити розуміння структурної організації програмного продукту i визначило специфікацію задач реалізації програмного комплексу інформаційної системи моніторингу успішності студентів, експериментальне дослідження якого підтвердило доцільність проектних рішень.

Аналіз останніх досягнень у сфері багатовимірного аналізу даних засвідчив, що найбільш повним і гнучким інструментарієм для створення OLAP-кубів, процедур, що зберігаються, і представлень є MS SQL Server. Безвідмовна робота, орієнтація на великі масиви даних і підтримка багатокористувацького доступу робить дану СУБД єдиним варіантом для розміщення БД навчального процесу і платформою для аналізу даних. Слід зауважити, що проектування інтерфейсів для клієнтських додатків MS SQL Server потребує IT-фахівців із високим рівнем знань у галузі. Однак, досвід закордонних транснаціональних корпорацій свідчить про успішне використання варіанту реалізації систем обробки даних на базі технологій Microsoft, що суттєво знижує витрати на реалізацію клієнтських додатків, але чомусь цей досвід не набув популярності в нашій країні. Мова йде про реалізацію програмного комплексу інформаційних систем на основні архітектури клієнт/сервер на платформі MS SQL Server iз реалізацією інтерфейсів засобами MS Access, де передбачений спеціалізований вид додатків проект MS Access. Такий варіант дозволяє:

1. Реалізувати інтерфейс користувача з найменшими витратами.

2. Гарантує наявність необхідного ПЗ на всіх робочих станціях користувачів (MS Access входить до пакету MS Office, MS SQL Server Express є безкоштовною платформою).

3. Не потребує до навчання користувачів - основам роботи з MS Access зараз навчають навіть школярів.

4. I, головне, звітність системи користувач може формувати власноруч iз використанням майстрів звітності, конструкторів та засобів багатовимірного аналізу, 
що їх надає MS Access. Причому особисто для себе з урахування завдань, що виникають на його робочому місці.

Підтримка безперебійної роботи БД під керівництвом MS SQL Server у такому випадку ненабагато збільшить коло завдань, що стоять перед штатним системним адміністратором ВН3, а, отже, може бути додана до його посадових обов'язків без необхідності вводити додаткові посади або витрачати кошти на сторонніх фахівців.

Microsoft SQL Server є найкращим варіантом платформи для організації бази даних системи, ще й тому, що він забезпечує функціонування промислової БД відповідно з існуючими міжнародними стандартами керування даними і захисту даних, організовує роботу з таблицями, запитами у доступній для користувача формі, забезпечує відповідний рівень надійності й відмовостійкості функціонування програмного комплексу під час операцій з управління даними. Інструментарій бізнесаналізу, що входить до складу платформи забезпечує подальші можливості щодо розвитку й удосконалення проектованої системи і гнучку інтеграцію 3 іншими інформаційними система навчального закладу. Засоби захисту даних й аутентифікації користувачів забезпечують надійні механізми підтримки конфіденційності даних відповідно до законодавчих актів нашої країни. У комплектації Express ця платформа э безкоштовною.

Microsoft Office Access 2010 обраний для проектування інтерфейсів користувача, оскільки він не потребує додаткових витрат на ліцензування, тому що входить до стандартних засобів MS Office, які встановлені на комп'ютерах навчальних закладів. більшість користувачів ПК не потребують донавчання роботі 3 даною СУБД, отже, мають можливість самостійно змінювати і доналаштовувати зручні для них і потрібні для звітності зрізи представлення даних, що є в системі. Також для користувача зажди доступним є інструментарій OLAP у вигляді зведених таблиць MS Access. Єдиною відмінністю цього інструмента класичних кубів $є$ те, що це статичні, а не динамічні таблиці. Однак завдяки можливості оновлення даних за запитом користувача даною відмінністю можна знехтувати.

Для збереження даних і забезпечення подальшої ефективної обробки даних було спроектовано схему БД засобами CASE-додатку ALLFussion Process Modeler. Структура БД визначена у формі «сніжинки», що спрощує підготовку даних для OLAP аналізу.

Типовий інтерфейс системи розподілу рейтингових рівнів студентів розроблено 3 використання СКБД Microsoft Office Access 2010. Інтерфейс системи розроблено 3 урахуванням максимальної ергономічності для оптимізації пристосування користувача до системи.

На рис. 5 зображено інтерфейс системи обліку успішності студентів. Першим кроком це $\epsilon$ аутентифікація користувача. У системі передбачена можливість реєструвати користувача або проходити аутентифікацію. Якщо прийнятий пароль неправильний, - система видасть помилку і буде відображати лише форми, функції яких будуть не активними. У разі правильного підключення до системи у лівому вікні 3'являться таблиці бази даних, набір представлень і процедур, що зберігаються, відповідно до рівня доступу користувача.

Інтерфейс для введення або перегляду даних передбачає можливість редагувати списки студентів, переглядати або вводити навчальний план, переглядати рейтингове оцінювання. У закладці «Аналіз успішності», зображеній на рис. 6, представлено перелік багатовимірних таблиць аналізу успішності. У даній вкладці можливо переглядати багатовимірні звіти з поточної успішності студентів за такими вимірами як: група, період, дисципліна, високий рівень успішності, відповідність умовам 
отримання стипендії на наступний семестр тощо. Такі зрізи є типовими, тому були реалізовані в прототипі системи.
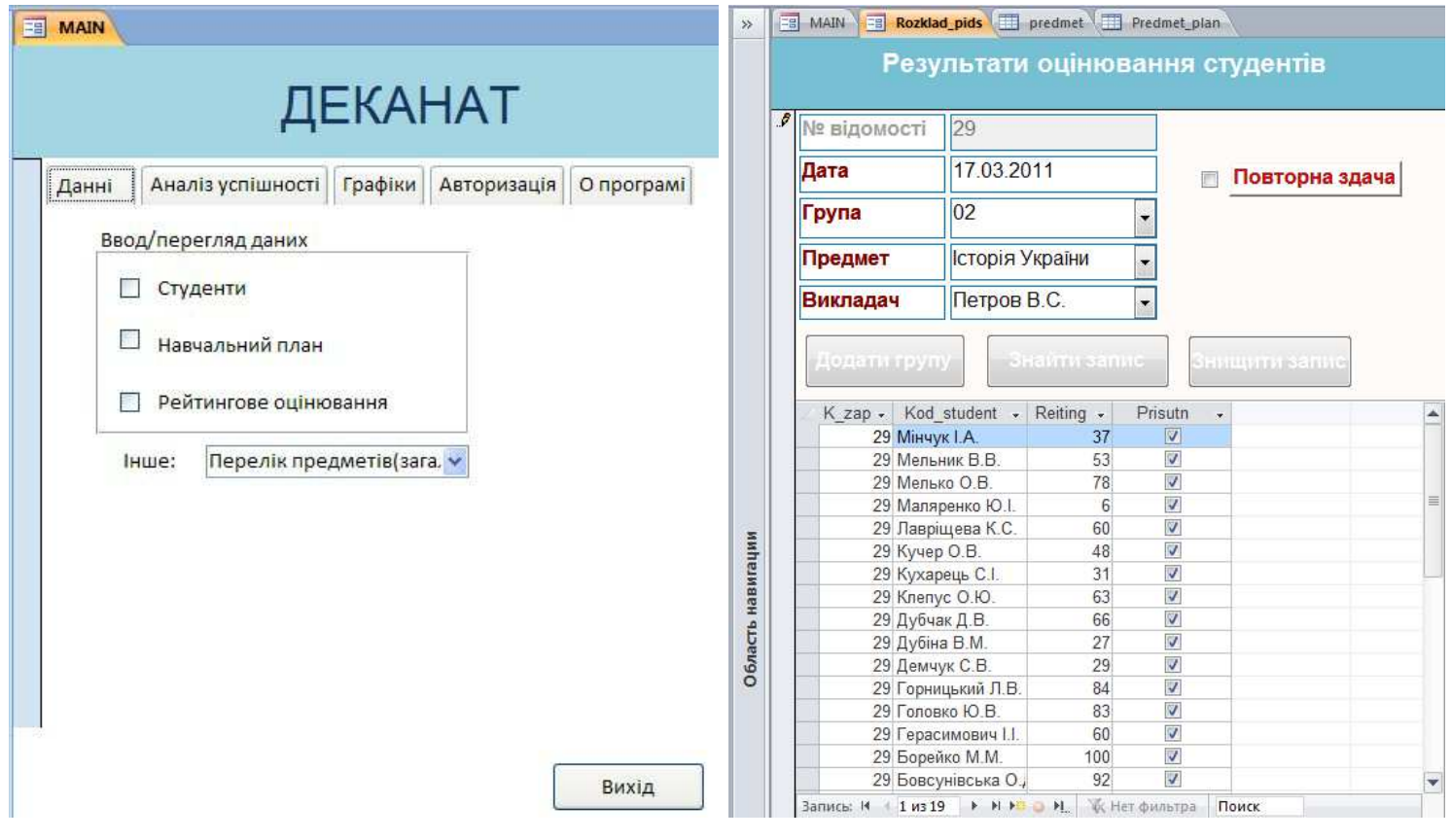

Рис. 5. Інтерфейс системи

У цьому випадку база даних, яка розміщена на сервері, служить постачальником інформації для багатовимірної бази даних, що є набором об'єктів, які дозволяють маніпулювати даними відповідно до потреб окремого користувача. Основними класами цих об'єктів є виміри і показники. До вимірів відносяться множини значень (параметрів), за якими відбувається індексація даних, у нашому випадку: період, група, дисципліна, викладач тощо. Кожен вимір заповнюється значеннями 3 відповідних таблиць вимірів сховища даних. Сукупність вимірів визначає простір досліджуваного процесу. Під показниками розуміються багатовимірні куби даних (гіперкуби).

У гіперкубі містяться самі дані, а також агрегатні суми за вимірами, що входять до складу показника. Показники становлять основний зміст машинної бази даних i заповнюються відповідно з таблицею фактів. Уздовж кожної осі гіперкуба дані можуть бути організовані у вигляді ієрархії, що є різними рівнями їх деталізації. Це дозволяє створювати ієрархічні вимірювання, за яких здійснюється агрегування або деталізація представлення даних. Типовим прикладом ієрархічного виміру служить таблиця успішності студентів групи, згрупована за семестрами і дисциплінами з деталізованими підсумками за сумою рейтингових балів за семестр.

3 відповідних таблиць вимірів сховища даних запитовими технологіями отримано динамічні набори даних, що $є$ основою для багатовимірних представлень. Такими запитами є: сумарний поточний рейтинг по групі, рейтинг студентів за семестрами і за період навчання, список усіх боржників, які не здали сесію. Дані запити розташовані на сервері у вигляді процедур, що зберігаються, і представлень. Використовуючи дані процедури, користувач може перебудовувати зовнішній вигляд зведених таблиць i діаграм, що запропоновані у прототипі системи за власною потребою, позаяк усі поля, наявні у звіті, їм доступні. За бажанням користувач може створювати додаткові запити на вибірку даних, використовуючи майстер або конструктор запитів і на їх основі будувати багатовимірні підсумкові таблиці. 
Наприклад, запит для аналізу успішності студентів без урахування перездач, можна використати як основу для звіту про стипендіатів - виведення списків студентів, які отримують стипендію і навчаються на «добре» і «відмінно».
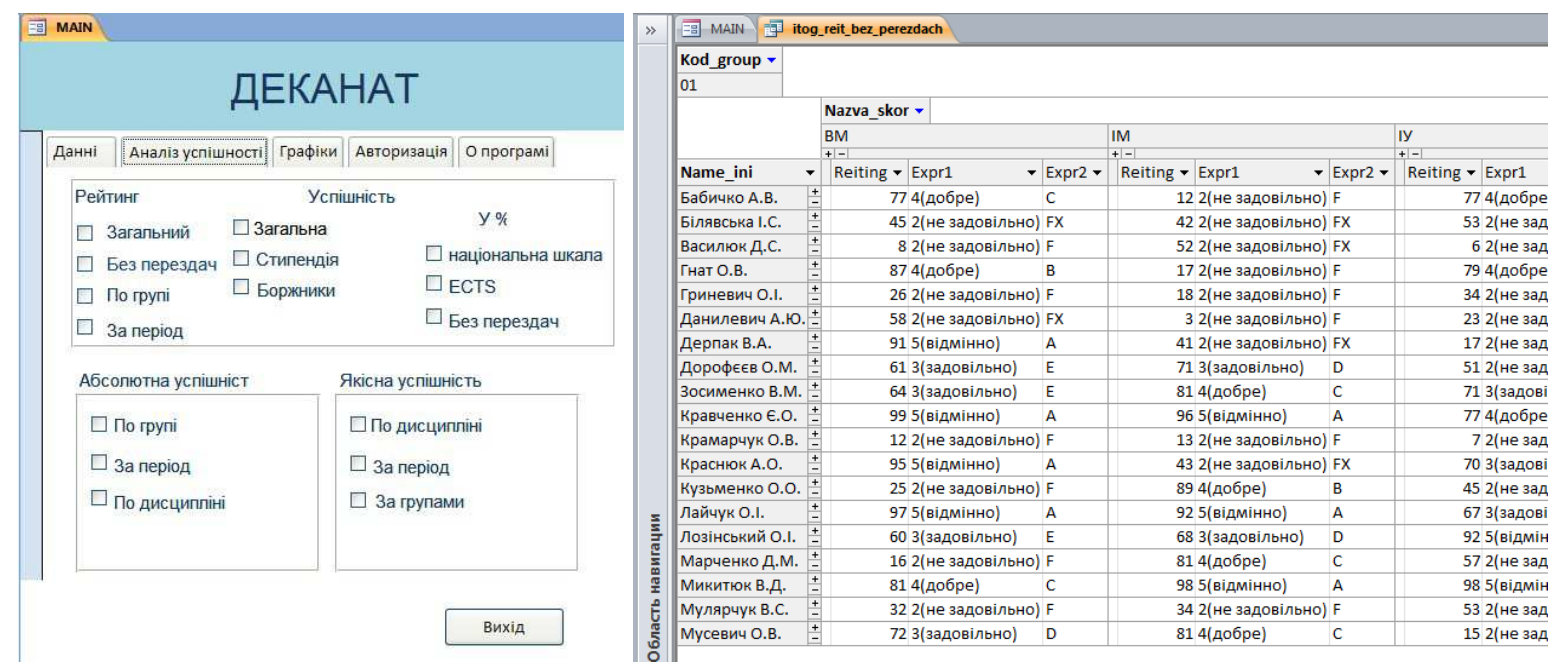

Рис. 6. Форма аналізу успішності студентів

Закладка «графіки», представлена на рис. 7, містить у собі форму з функціями, які виводять на екран гістограми за рейтингами студентів як у національній шкалі, так і в ECTS вигляді.
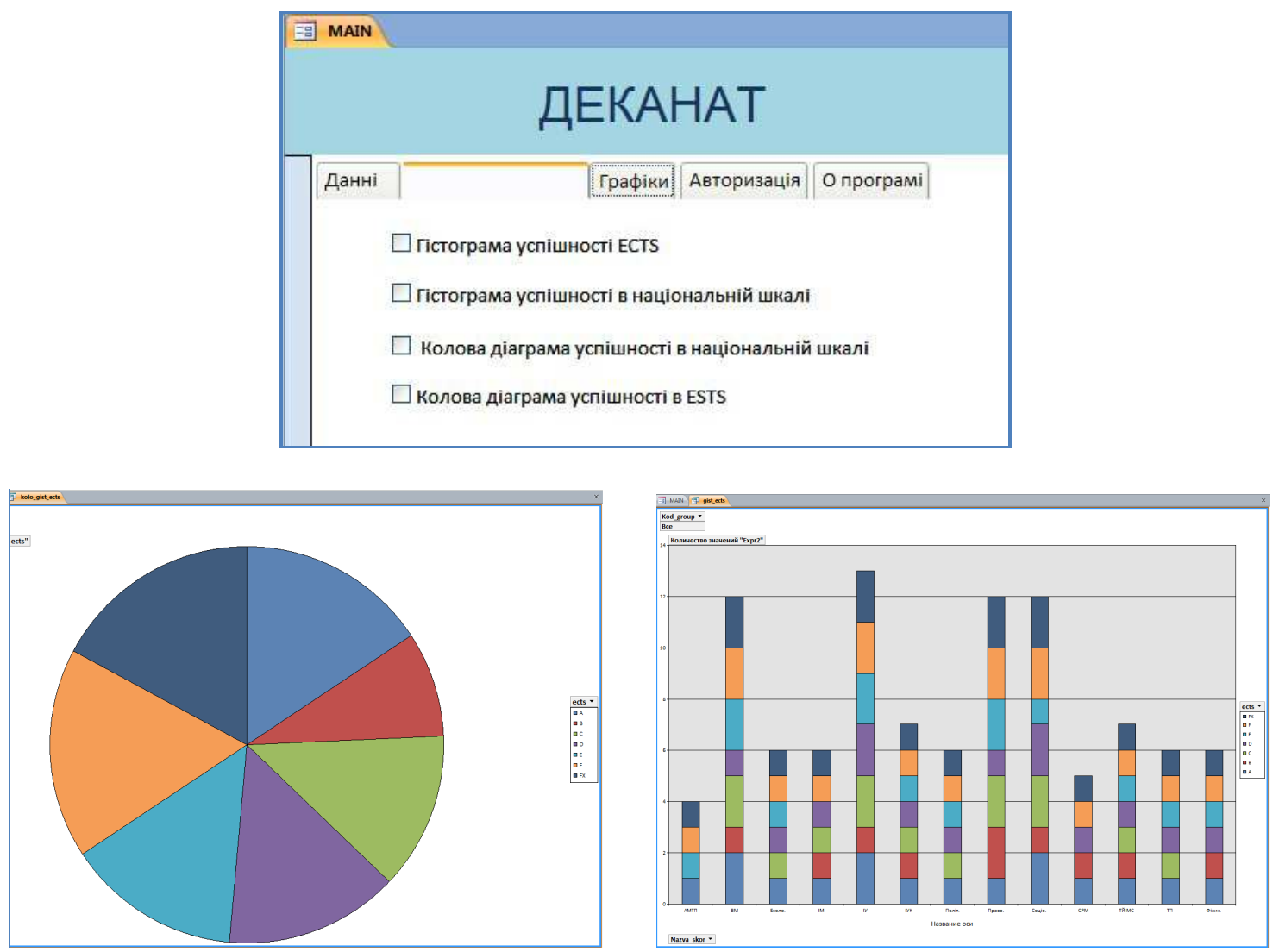

Рис. 7. Фрагменти відображення даних - вкладка «рафіки» 
Основними процедурами обробки даних у системі є запити, реалізовані на боці сервера як представлення і процедури, що зберігаються, та функції для розрахунку таких специфічних параметрів, як оцінки за різними шкалами.

До прототипу системи включені лише типові види звітів, позаяк користувач може змінювати структуру таблиць, виходячи з власних потреб. Якщо базових представлень не достатньо, користувач може створити нові за допомогою конструкторів і майстрів запитів. Щоб нові запити буди доступні іншим користувачам, достатньо їх зберегти не в екземплярі клієнтського додатку, а на боці сервера як представлення.

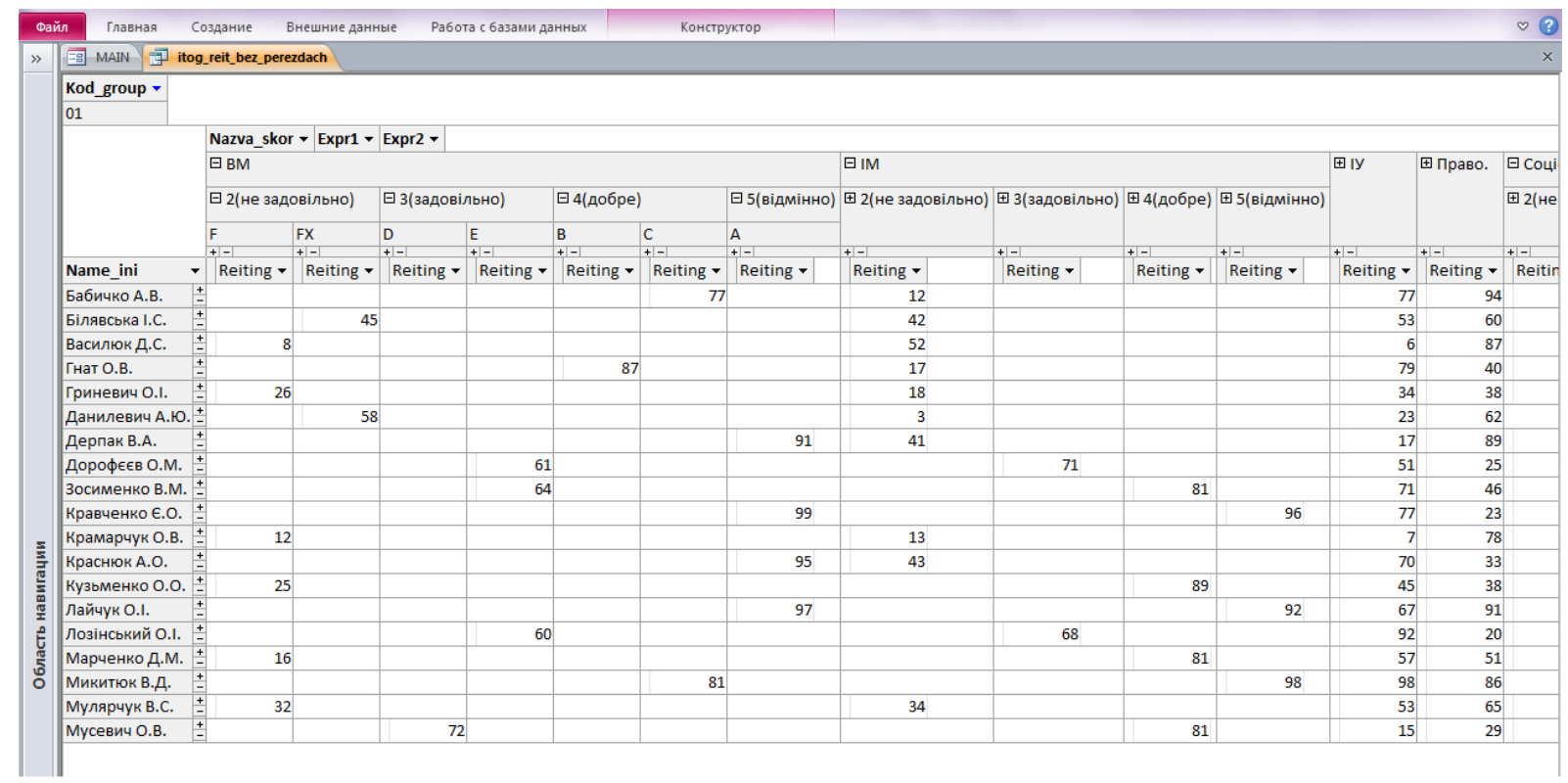

Рис. 8. Форма аналізу успішності студентів із доданими рейтинговими балами

Отже, маючи базові навички роботи в MS Access, користувач може доналаштувати систему за власними потребами без необхідності втручання сторонніх спеціалістів.

\section{4. ВИСНОВКИ ТА ПЕРСПЕКТИВИ ПОДАЛЬШИХ ДОСЛІДЖЕНЬ}

Розроблена інформаційна система моніторингу успішності студентів дозволяє підвищити ефективність і результативність діяльності працівників деканату, створити комп'ютеризовану інформаційну базу для надання необхідної статистичної інформації щодо успішності студентів, проводити аналіз стану і динаміки якості навчання. Використання багатовимірних технологій обробки даних робить дану систему гнучкою i такою, що може задовольнити всі інформаційні потреби користувача в формах представлення інформації під час аналізу стану навчального процесу. У подальшому доцільним $\epsilon$ передбачити інтеграцію даної системи 3 іншими інформаційними підсистемами ВНЗ.

\section{СПИСОК ВИКОРИСТАНИХ ДЖЕРЕЛ}

1. Про Державну національну програму «Освіта» («Україна XXI століття») : Постанова Кабінету міністрів України від 03.11.93 № 896 [Електронний ресурс]. - Режим доступу : http://zakon.rada.gov.ua/cgi-bin/laws/main.cei?nreg=896-93-\%EF\&p=1286561141979428.

2. ДСТУ ISO 9001:2009 «Система управління якістю. Вимоги» [Електронний ресурс]. - Режим 
доступу : http://www.gerelo.dp.ua/index/info_dstu_iso_900 1-2009.html.

3. Лазарев Г. И. Управление современным университетом : монография / под общ. ред. проф. Г. И. Лазарева. - Владивосток : Изд-во ВГУЭС, 2005. - 324 с.

4. Андреев А. Н. Классификация OLAP-систем вида хOLAP [Електронний ресурс] / Андреев А. Н. // CIT Forum, 2010. - Режим доступу : http://citforum.ru/consulting/BI/xolap_classification/.

5. Krzysztof J. Cios. Data Mining: A Knowledge Discovery Approach / Krzysztof J. Cios // Springer. 2007. Мацяшек Л. А. Аналіз вимог та проектування систем. Розробка інформаційних систем 3 використанням UML / Л. А. Мацяшек. - К. : Вільямс, 2002. — 432 с.

Матеріал надійшов до редакиї 20.11.2013 p.

\title{
ОLАР-ТЕХНОЛОГИИ ДЛЯ МОНИТОРИНГА УСПЕВАЕМОСТИ СТУДЕНТОВ В УСЛОВИЯХ РЕЙТИНГОВОЙ СИСТЕМЫ ОЦЕНИВАНИЯ ЗНАНИЙ
}

\author{
Сугоняк Инна Ивановна \\ кандидат технических наук, доцент кафедры программного обеспечения систем \\ Житомирский государственный технологический университет, г. Житомир, Украина \\ isygon@mail.ru
}

\begin{abstract}
Аннотация. В статье освещены проблемные аспекты внедрения информационных технологий в образовательную деятельность вузов, определены задачи комплексного мониторинга успешности студентов, проанализированы современные технологии многомерного анализа данных, в частности, концепция Data Mining и OLAP-технологии, определены возможности и направления использования средств многомерного анализа данных в системах мониторинга успеваемости студентов, выполнено объектноориентированное проектирование программного комплекса системы с использованием языка UML, обоснован выбор платформы реализации и приведено описание прототипа системы.
\end{abstract}

Ключевые слова: рейтинговая система оценивания знаний; OLAP-технологи; информационные системы в образовании.

\section{OLAP-TECHNOLOGY TO MONITOR STUDENT'S ACHIEVEMENT UNDER CONDITIONS OF RATING SYSTEM FOR KNOWLEDGE ASSESSMENT}

\author{
Inna I. Suhoniak \\ $\mathrm{PhD}$ (technical sciences), assistant professor of the Department of software systems \\ Zhytomyr State Technological University, Zhytomyr, Ukraine \\ isygon@mail.ru
}

\begin{abstract}
The article deals with the problematic aspects of the information technologies deployment in the university educational process, defines the tasks of the integrated monitoring of student's academic achievement. In the article it has been analyzed the modern technologies of multidimensional data analysis, Data Mining and OLAP-technologies, determined directions and possibilities of using multidimensional data analysis in monitoring of student's academic achievement, performed an object design of software systems using UML, substantiated the choice of platform development and described a prototype of the system.
\end{abstract}

Keywords: rating system for knowledge assessment; OLAP-technology; information systems in education.

\section{REFERENCES (TRANSLATED AND TRANSLITERATED)}

1. On the State National Program «Education» («Ukraine XXI Century»): Cabinet of Ministers of Ukraine from 03.11.93 № 896 [Online]. — Available from : http://zakon.rada.gov.ua/cgibin/laws/main.cei?nreg=896-93-\% EF \& p = 1286561141979428. (in Ukrainian) 
2. EN ISO 9001:2009 «Quality Management System. Requirements» [Online]. — Available from : http://www.gerelo.dp.ua/index/info_dstu_iso_900 1-2009.html. (in Ukrainian)

3. Lazarev G. I. Management by Modern University : monohrafyya / pod Society. yet. prof. GI Lazarus. Vladivostok : Izd VHUES, 2005. - 324 p.(in Russian)

4. A. N. Andreev. Classification OLAP-conditioning systems xOLAP [online] / A. N. Andreev // CIT Forum, 2010. - Available from : http://citforum.ru/consulting/BI/xolap_classification/. (in Russian)

5. Krzysztof J. Cios. Data Mining: A Knowledge Discovery Approach / Krzysztof J. Cios // Springer, 2007. (in English)

6. Matsyashek L. A. Requirements analysis and system design. Development of information systems using UML / L. A. Matsyashek. — K. : Williams, 2002. — 432 p.(in Ukrainian) 